\title{
White Hegemony in the (Re)Birth of Brazil
}

\author{
Benito $\mathrm{Cao}^{1}$
}

\section{Abstract}

On 7 September 1822, Dom Pedro de Alcantara, Prince Regent and future Emperor of Brazil, uttered the most famous cry in Brazilian history: 'Independence or death!' The symbolic power of the royal cry - known as the Grito de Ipirangahas served to idealise Brazilian independence: the (re)birth of Brazil. The Grito de Ipiranga has been interpreted as the culmination of a peaceful process of political integration destined to give birth to a single nation-state in Portuguese America. This article examines this idealised and teleological portrait of Brazilian independence. The analysis extends from the first anti-colonial manifestations in the early sixteenth century to the consolidation of national unity in the mid nineteenth century. This wide historical framework enables us to discern the criteria used to select the events and figures that came to be part of the national(ist) discourse of Brazilian independence. The analysis reveals how this portrait of Brazilian independence locks out of the nationalist imaginary all those who did not participate in the formal process of independence, managed by Luso-Brazilians. This narrative of the (re)birth of Brazil turns independence into a symbolic pillar of white hegemony in Brazil.

\section{White Hegemony in the (Re)Birth of Brazil}

On 7 September 1822, Dom Pedro de Alcantara, Prince Regent and future Emperor of Brazil, uttered the most famous cry in Brazilian history: 'Independence or death!' The symbolic power of the royal cry - known as the Grito de Ipirangahas served to idealise Brazilian independence: the (re)birth of Brazil. The Grito de Ipiranga has been interpreted as the culmination of a peaceful process of political integration destined to give birth to a single nation-state in Portuguese America - an interpretation common to both conservative and progressive canonical historians, such as Francisco Varnhagen, João Capistrano de Abreu, Manuel de Oliveira Lima and Manoel Bomfim. The peaceful character of that

1 Email: <benito.cao@adelaide.edu.au> 
process is attributed to the political wisdom of the (white and male) elite of colonial Brazil and their ability to minimise internal conflicts and avoid a direct confrontation with Portugal. This, the argument goes, enabled a smooth transition from colony to nation, without the bloodbath and fragmentation that characterised the process of independence in Spanish America. The result is a historiography that privileges the trope of cordiality and the historical agency of Luso-Brazilians, turning independence into a symbolic pillar of white (and male) hegemony in Brazil.

The narratives and the studies of Brazilian independence tend to focus on the period 1808-22, with the turning point being the transfer of the seat of the Portuguese Crown to Rio de Janeiro in 1808, following the invasion of Portugal by Napoleonic troops. The transfer posed a crucial challenge to the colonial relations between Brazil and Portugal. Yet its impact on the process of independence had less to do with the separation from Portugal than with the impulse to the political and symbolic unity of Brazil. The 13-year residency of the Portuguese Crown in Rio de Janeiro brought a series of reforms that promoted the unification of the colony: improvements of transport and communication between population centres, reforms in taxation and the administration of justice, the creation of naval and military academies as well as of schools of medicine and surgery, the expansion of coffee production under royal protection, the building of textile factories, the beginning of the iron and steel industries, the establishment of the Bank of Brazil, the creation of the National Library, and the establishment of the Royal Printing Office.

The separation from Portugal did not alter the Eurocentrism that was at the heart of the formation and formulation of Brazil(ianness). Independence signalled 'the climax of three centuries of changing attitudes toward Portugalfrom inferiority, to equality, to superiority', ${ }^{2}$ but the Brazilian Empire that came about was to be built upon Eurocentric cultural foundations, imitating the nations of the North Atlantic, in particular France - at the time the foremost symbol of (Western) modernity in Brazil. ${ }^{3}$ Brazilian Indians and Afro-Brazilians would be denied a place in the formal process of Brazilian independence and the foundation of the Brazilian Empire - other than as the 'Other' of (Western) modernity. This same Eurocentrism would be imbued in the formulation of Brazilian independence in the canonical texts of Brazilian historiography, even

2 Burns, E. B. 1968, Nationalism in Brazil: A historical survey, Frederick A. Praeger, New York, Washington, DC, and London, p. 30.

3 Needell, J. D. 1987, A Tropical Belle Epoque: Elite culture and society in turn-of-the-century Rio de Janeiro, Cambridge University Press, Cambridge. 
by those who, like Manoel Bomfim, praised the people as the central actors of Brazilian politics. The privileged actors in his and other canonical accounts of Brazilian independence were invariably the Luso-Brazilians. ${ }^{4}$

This article examines the idealised and teleological portrait of Brazilian independence that dominates canonical accounts and general histories of Brazil. The analysis extends from the first anti-colonial manifestations in the early sixteenth century to the consolidation of national unity in the mid nineteenth century. This wide historical framework will enable us to discern the criteria used to select the events and figures that came to be part of the national(ist) discourse of independence. Shifting the attention towards historical events that preceded and followed the period 1808-22 - that is, bringing events usually placed at the margins of canonical accounts into sharp focus - enables us to see Brazilian independence in a new light, one that reveals its inherent Eurocentrism. The patterns of inclusion and exclusion are examined in three separate sections. The first focuses on the so-called nativist movements: a series of colonial revolts that was invented as national (or proto-national) events after the independence of Brazil. The second examines the different ideological reception of the two most emblematic colonial revolts inspired by the principles of the Enlightenment: the Inconfidência Mineira (1789) and the Inconfidência Bahiana (1798). The final section examines the different treatment accorded to the rebellions that followed the independence of Brazil.

The analysis reveals a double narrative that serves to deny the political nature of popular rebellions protagonised by Brazilian Indians and Afro-Brazilians. The nationalist accounts produce two separate narratives: a narrative of political revolts (led by whites) seeking to liberate the nation from external control, which were eventually successful, and with little, if any, bloodshed; and a narrative of social revolts (led by non-whites) seeking to fulfil particular needs, driven by emotions and violence, which were responsible for immense bloodshed, but were dissociated from the struggle for Brazilian independence. This article posits that this double narrative allows traditional historiography to create a hierarchy of revolts in which the political agency of Brazilian Indians and Afro-Brazilians is ignored, marginalised or misrepresented. This narrative

\footnotetext{
4 This narrative of Brazilian independence also found ideological affirmation in the work of Gilberto Freyre, the chief author of the formulation of hybridity as the essence of Brazilianness. Freyre defined Brazil as the product of cultural syncretism and sexual miscegenation and argued that Brazilians should take pride in their culturally and racially mixed heritage, which had enabled the emergence of a racial democracy in Brazil. His celebration of hybridity was, however, no impediment to placing whiteness at the heart of historical narratives of Brazilian politics. He argued that revolutions, and even the abolition of slavery, had been relatively peaceful - in his words, white rather than bloody — and he attributed this to the cordiality of the Portuguese and their Brazilian descendants, the Luso-Brazilians. See Freyre, G. 1959, New World in the Tropics: The culture of modern Brazil, Alfred A. Knopf, New York, pp. 15-16.
} 
strategy entrenches white hegemony and Eurocentrism at the heart of Brazilian independence, effectively erasing the political agency of Brazilian Indians and Afro-Brazilians from the historical memory of Brazil.

\section{Nativists and (the) Others in Brazilian Nativism}

The portrait (and process) of Brazilian independence cannot be properly understood without the analysis of Brazilian nativism - a nationalist narrative that presents the history of Portuguese America as a teleological sequence of events destined to culminate in the independence of Brazil. The term nativism has been used in different ways in Brazilian history. It is, however, possible to identify two main expressions of nativism in colonial Brazil: nativist narratives and nativist movements. Nativist narratives are literary expressions of affection and exaltation of the land of Brazil. These narratives did not contribute to the formation of Brazil during the colonial period - not least because most of them were published only in the late nineteenth century - but were crucial for the (re)construction of colonial history as well as for the invention of the colonial past of the nation after independence. Nativist movements are uprisings against the colonial regime carried out by people born in Brazil. This section examines so-called nativist movements - a series of regional colonial revolts that was invented as national (or proto-national) after independence-as well as other important conflicts from the same period that are excluded from the definition of Brazilian nativism. The analysis will reveal the ideological character of the national(ist) portrait of Brazilian independence.

$$
* * *
$$

Nativism remits ultimately to the question posed by Barbosa Lima Sobrinho in his book Desde quando somos nacionalistas? His answer is unequivocal: the first expressions of nationalism date back to the moment the first colonists perceived their interests as being different from those of the metropolis and decided to act upon that perception. ${ }^{5}$ Sobrinho presents the struggles of the Portuguese colonists, and their Brazilian descendants, against the Spanish (in the south), the French (in the centre), and the Dutch (in the north) as precedents of the nationalist sentiment that would eventually pit Brazilians against Portuguese. This Eurocentric interpretation-one in which all historical agents are Europeans and/or descendants of Europeans - is present in both conservative and progressive canonical narratives of Brazilian history. ${ }^{6}$

5 Sobrinho, B. L. [1963] 1995, Desde quando somos nacionalistas?, Vozes, Petrópolis, pp. 9-10.

6 See, for example, Francisco Varnhagen, História geral do Brasil (1854-57); João Capistrano de Abreu, Capitulos de história colonial (1907); Manuel de Oliveira Lima, Formação histórica da nacionalidade Brasileira 
In these narratives, Brazil emerges from the struggle of the Portuguese against the other colonial powers: Spain, France, Holland and Britain. The historical narratives do not ignore the participation of the indigenous population in the early disputes over the colonisation of Brazil. In fact, the alliance between the Indians and the Portuguese is often defined as essential for the Portuguese colonisation of Brazil and the expulsion of the other European contenders. What is interesting here, however, is the fact that only the alliances between the Portuguese and the Indians get the seal of Brazilianness. This means that the Brazilianness of this alliance can derive only from the presence of the Portuguese. Otherwise their enemies would also have to be considered Brazilian. After all, the French also formed strong and lasting alliances with the Indians.

The other colonial conflicts incorporated as part of Brazilian nativism are those revolts carried out by the Portuguese colonists and their descendants against the colonial authorities and the Portuguese Crown. The first of these conflicts to gain historical prominence took place in the State of Maranhão in 1684, and came to be known as the Revolta de Beckman. It is important to note here that, in Portuguese America, there were two official Brazils for more than 150 years (c. 1618-1774): the State of Brazil and the State of Maranhão. The two states were cut off from one another and only loosely governed from Portugal. The two states came together to form the State of Brazil, with a capital in Rio de Janeiro, in 1774. Rogério Forastieri da Silva notes quite correctly that if this separation had been perpetuated there would have been a great chance that not one but two nation-states would emerge from Portuguese America: Brazil and Maranhão. In that case, the Revolta de Beckman would not be a nativist movement of Brazil, but of this other country, Maranhão. ${ }^{7}$

The Revolta de Beckman was one of several revolts carried out by the colonists in the tradition of the old-regime rebellions: food riots and tax rebellions. In Portuguese America, these included the Revolta da Cachaça in Rio de Janeiro (1660-61), the Revolta da Maneta in Salvador (1711), the Revolta de Pitangui in Minas Gerais (1718), and the Revolta de Felipe dos Santos in Vila Rica (1720). These revolts forged a history of resistance against the fiscal pressures of the Portuguese Crown. There is, however, a tendency to invoke these revolts as precedents of nationalism and Brazilianness, even though they were always related to economic issues, and were of regional character. Thus, for example, Sobrinho credits the Revolta de Beckman with having established the 'framework of nationalism' that would set up the road towards the independence of Brazil, ${ }^{8}$ even though, as noted above, the revolt could as easily have set up the road towards the independence of Maranhão.

(1911); Manoel Bomfim, O Brasil na América (1929) and O Brasil-Nação (1931).

7 Silva, R. F. da 1997, Colônia e nativismo: A história como 'biografia da nação', Hucitec, São Paulo, p. 85.

8 Sobrinho, Desde quando somos nacionalistas?, p. 24. 
The attribution of nationalism and Brazilianness to the actions of the colonists is even more acute in the two conflicts that have come to best symbolise nativism: the Guerra dos Emboabas (1707-09) and the Guerra dos Mascates (1710-11). The Guerra dos Emboabas was a small-scale civil war between two groups of colonists over the control and exploitation of the goldmines discovered in Minas Gerais. The first group comprised pioneers from São Paulo (Paulistas) and their Indian auxiliaries, servants and slaves. The second group comprised newcomers from Portugal and from other parts of Portuguese America, together with their slaves - mainly of West African origin. The Paulistas resented the presence of any rivals on what they considered to be their property, viewing them as 'foreigners' and 'outsiders', and derisively referring to them as emboabas (chicken-feet). ${ }^{9}$

The struggle of the Paulistas to retain control of the mines has typically been interpreted as an expression of Brazilian nativism. The classic case is José Soares de Melo's Emboabas (1929), subtitled 'Chronicle of a nativist revolution'. ${ }^{10}$ This interpretation sidelines the fact that the claims of possession of the Paulistas were not based on a politics of identity but on the right of discovery - that is, on the fact that they were the first to find the mines. In any case, the interpretation of the conflict as a proto-national(ist) revolution betrays the early identification of Brazilianness with the identity of the colonists. After all, when the Guerra dos Emboabas is posed in terms of a conflict of identities, the identities in conflict are those of two groups of colonists: the Paulistas and the Portuguese.

The conflict usually considered the quintessential expression of Brazilian nativism is the Guerra dos Mascates, a short-lived civil war between the two most important populations of Pernambuco: the Brazilian-born planter aristocracy of Olinda and the Portuguese merchants who operated from Recife. The local nobility (known as mazombos) resented the privileges granted to the economic activities of the foreign traders (derisively referred to as mascates: peddlers). Their increasing disaffection with the colonial regime turned into open conflict with the colonial authorities after the decision of the Portuguese Crown to free Recife from the political control of Olinda. The repression that followed squashed the vague aspirations of autonomy voiced by some of the mazombos, but their stand against the Portuguese Crown would enter the national imagination through the epic narrative of José de Alençar, entitled Guerra dos Mascates (1870). It was in fact only after the publication of this book

9 Barreiros, E. C. 1984, Episodios da Guerra dos Emboabas e sua geografia, Itatiaia, Belo Horizonte, pp. 51-5. 10 Melo, J. S. de 1929, Emboabas: Crónica de uma revolução nativista, Governo do Estado de São Paulo, São Paulo. 
that a minor conflict previously referred to as 'sedition' or 'alteration' became known as the Guerra dos Mascates. Subsequently, the revolt was defined as a proto-nationalist affirmation: 'a nativist movement precursor of independence.'11

$$
* * *
$$

The detailed accounts of the Portuguese defensive wars against their European rivals and of the conflicts between colonists and the Portuguese Crown stand in stark contrast with the scant attention paid to the actions of Indians and Africans. In his classic study of the colonial historiography, José Honório Rodrigues dedicates two pages to indigenous rebellions, five pages to black rebellions, and 30 pages to the rebellions of the colonists. ${ }^{12}$ The space allocated to each group reflects the little attention paid to the campaigns launched by the Indians against the Portuguese in the historiography of colonial Brazil. Significantly, when they appear, they are defined as offensive wars, thus legitimising their violent repression as well as reversing the logic of the situation, by presenting those who resisted colonisation as the aggressors. Moreover, the actions of the Indians are commonly interpreted in these narratives as expressions of barbarism and resistance to civilisation.

The nationalist historiography has departed from this line of argument only to incorporate into the definition of Brazilianness the courage displayed by the Brazilian Indians. This reappraisal of indigenous anti-colonial resistance, however, has been highly selective, and retains the basic Eurocentric tenor that informed colonial historiography. This point can be illustrated by comparing the different treatment accorded to the two most important indigenous rebellions in colonial Brazil: the Guerra dos Tamoios (c. 1540-70), and the Guerra dos Bárbaros (c. 1650-1720).

The Guerra dos Tamoios pitted a coalition of several Tupi tribes (in alliance with the French) against the Portuguese. The Confederation of the Tamoios was the first great coalition of indigenous peoples to rebel against the Portuguese colonisation of Brazil. The significance of this coalition can hardly be overestimated, especially given the fragmentation and intertribal warfare that characterised relations amongst the indigenous peoples of this part of the Americas. The formation of the coalition showed the political will to overcome traditional rivalries in their effort to resist the colonial expansion of the Portuguese. The Confederation of the Tamoios was defeated only after the arrival of reinforcements under the Governor-General Mem de Sá to aid the

\footnotetext{
11 Melo, M. 1941, A Guerra dos Mascates como Afirmação Nacionalista, Instituto Arqueológico e Geográfico Pernambucano, Pernambuco, p. 51.

12 Rodrigues, J. H. 1979, História da história do Brasil. 1a Parte: Historiografia colonial, Companhia Editora Nacional, São Paulo, pp. 317-56.
} 
campaign of Estácio de Sá. The superior artillery and cavalry of the Portuguese and the diseases against which the indigenous peoples had no immunological resistance sealed the fate of the Tamoios in 1567.

The Tamoios have received little attention in Brazilian historiography. Their courageous stance against the Portuguese Crown, however, turned them into useful symbolic material during the struggle for the independence of Brazil. Their courage was invoked, for example, in the newspaper of nativist inspiration published by José Bonifácio de Andrada e Silva: O Tamoio. The temporary hostility against Portugal and the need to formulate a distinctive national identity following independence led to the development of a literary movement known as Indianism. One of the main exponents of this movement was $A$ Confederação dos Tamoios (1857), by Domingos Gonçalvez de Magalhães. The Tamoios were portrayed as noble savages fighting against the Portuguese. By the late nineteenth century, however, the hostility against Portugal had receded, and with it the interest in the Brazilian Indians. In the end, the incorporation of the Tamoios in the discourse of independence was temporary and framed by literature rather than history; they were treated as literary figures rather than as historical agents. Moreover, rather than the chief of the Tamoios, Aimberê, the celebrated historical figure of the Guerra dos Tamoios is Estácio de Sá, the captain of the Portuguese forces, who entered history as the founder of Rio de Janeiro.

The Eurocentric treatment accorded to indigenous anti-colonial resistance in Brazilian nativism can be observed also in the so-called Guerra dos Bárbaros. This expression has been used to refer to two different but related conflicts: the Guerra do Reconcavo, in the hinterland of Bahia (c. 1651-79), and the Guerra do $A c ̧ u$, in the region of Pernambuco (c. 1679-1720). These wars followed the expansion of the cattle industry in the north-east, which began in earnest after the expulsion of the Dutch. The cattle expansion into the interior of the northeast was one of the most important stages in the conquest of Brazil and the annihilation of the Brazilian Indians. The struggle between the colonists and the Confederation of the Cariri was one of the most terrible conflicts in the history of Portuguese America. The conflict showed the strong and permanent resistance of the Brazilian Indians, but resulted in the massive annihilation of the indigenous population of the north-east. ${ }^{13}$

The Guerra dos Bárbaros is one of the most overlooked conflicts in the historiography of Brazil. Unlike the Guerra dos Tamoios, this revolt was not incorporated into the discourse of independence. Instead, the Guerra dos Bárbaros has been interpreted - as its very denomination indicates - as an

13 Pires, M. I. da C. 1990, Guerra dos Bárbaros: Resistência indígena e conflito no Nordeste colonial, Massangana, Recife. 
expression of barbarism and resistance to civilisation. The different treatment accorded to the two conflicts can be explained by the increasing nationalisation of the colonisation of Brazil. Thus, while the Guerra dos Tamoios was waged during the early years of colonisation - and therefore against an enemy who was born in Portugal - the Guerra dos Bárbaros was waged against an enemy who was born in Brazil. The Guerra dos Bárbaros was another courageous expression of anti-colonial resistance- only this time not against external colonisation but against internal colonisation. In sum, the incorporation of indigenous resistance into the national imagination is not only circumscribed to the world of literature, but also emptied of any possible connotation that might lead to questioning of the mythical cordiality of the relations between Brazilian Indians and LusoBrazilians.

The selective interpretation of the formation of a spirit of independence in Brazil is demonstrable also in the treatment accorded to the struggle against slavery. Slavery was a ubiquitous institution in Brazil for more than 300 years, and of critical importance to the political economy and social identity of Brazil. Slave labour fuelled the economic development of Brazil from the mid sixteenth century until the late nineteenth century. Slaves cultivated the plantations of sugar cane established at different times in Bahia, Pernambuco, Alagoas, Paraíba, Rio de Janeiro and São Paulo, as well as the plantations of tobacco and cacao in Pará and Bahia, cotton in Maranhão, Pará and Pernambuco, rice in Maranhão, and coffee in Rio de Janeiro and São Paulo. They participated in large numbers in the extraction of gold and diamonds in Minas Gerais and Goiás. They contributed to the development of the cattle industry of Rio Grande do Sul, Paraná and Santa Catarina, and to the commercialisation of herbs and spices from the Amazon. Slaves also provided most of the services required in the urban centres of Bahia, Rio de Janeiro and São Paulo.

The possession of slaves was open to everyone: men and women, rich and poor, nationals and foreigners, whites and blacks, free and freed, and there were even cases of slaves owning other slaves. Some studies have even suggested that the social and economic dream of freed men was the acquisition of slaves - that is, to complete the full transition from slave to master. ${ }^{14}$ This democratisation of slave ownership-for want of a better term-gave slavery a degree of flexibility and social and ideological penetration far larger than if it had been the privilege of a single group. In short, slavery fuelled the Brazilian economy, structured Brazilian society and shaped Brazilian mentality. Indeed, slavery was responsible not merely for the prosperity but for the very existence of

14 Marquese, R. de B. 2006, 'A dinâmica da escravidão no Brasil: resistência, tráfico negreiro e alforrias, séculos XVII a XIX', Novos Estudos CEBRAP, no. 74, p. 118. 
Brazil. ${ }^{15}$ But slavery was also a permanent threat to the social and political control exercised by the Luso-Brazilians. For these, the presence of black slaves threatened the safety and identity of Brazil. In this sense, it is not surprising that Brazilian independence - and later Brazilian abolition(ism) - would be shaped by a double fear: the fear of revolution and the fear of blackness. These fears - and the prejudices that went along with them-informed the process and the narratives of Brazilian independence. This is clearly observable in the historiographical treatment afforded to the formation of Palmares.

Palmares was the most important of a large number of quilombos (settlements of fugitive slaves) that were formed in Brazil. The quilombo of Palmares emerged in the Brazilian north-east in the early seventeenth century. Its political structure resembled that of a federal state with an elected monarchy. The ruler was a king elected for life by a council made up of the rulers of the settlements that constituted Palmares. The King ruled with the advice of the federal council and the support of officials and magistrates. The economy of Palmares was based on agricultural production, hunting and fishing, a dynamic craft sector, and trade with the surrounding populations. Palmares existed at the heart of Portuguese America as a political entity independent of the Portuguese Crown for almost a century. The inhabitants withstood frequent attacks from the Portuguese and the Dutch, until they were finally defeated in 1695.

The conflict between Palmares and the Portuguese Crown is no more or less nativist than any of the other conflicts between the inhabitants of Brazil and the Portuguese Crown. Palmares not only became 'the most prolonged episode at self-government attempted by the black peoples of Brazil', ${ }^{16}$ but one could even argue that the first independent state to emerge out of Portuguese America was not Brazil, but Palmares itself. After all, this was the only political entity independent of the authority of the Portuguese Crown in colonial Brazil. Yet, Palmares-like the anti-colonial resistance of the Brazilian Indians - is not considered part of Brazilian nativism, of the forging of the spirit of Brazilian independence. Instead, nativism gives coherence to a series of multiple anticolonial conflicts by effecting a selection that excludes indigenous resistance and black rebellion from the discourse of Brazilian independence.

15 Boxer, C. R. 1961, Four Centuries of Portuguese Expansion, 1415-1825: A succinct survey, Witwatersrand University Press, Johannesburg, p. 91.

16 Carneiro, E. [1947] 1958, O Quilombo de Palmares, (Second edition), Companhia Editora Nacional, São Paulo, p. 41. 


\section{The Colours of the Enlightenment in Colonial Brazil}

The transformation of Portuguese America into a nation-state began in the second half of the eighteenth century - a period defined by the crisis of absolutism and mercantilism, and the emergence of nationalism in Europe and the Americas. This period saw the territorial consolidation of Portuguese America in the Treaty of Madrid and the Treaty of Santo Ildefonso, the formal abolition of Indian slavery, the creation of the Diretório dos Indios, the expulsion of the Jesuits, the transfer of the colonial capital from Salvador to Rio de Janeiro, the abolition of the State of Maranhão and its integration into the State of Brazil, the consolidation of Portuguese as the official language of Brazil, and, last but not least, the arrival of the ideas of the Enlightenment.

The ideas of liberty and equality inspired a series of conspiracies in the late eighteenth century that came to be known as inconfidencias - a word coined by imperial historians to indicate a break of loyalty (literally: the lack or withdrawal of trust) from the Portuguese Crown. The inconfidências have been incorporated by nationalist historiography alongside nativist movements as precedents of Brazilian independence. They incorporate a new dimension, however, that sets them apart from earlier anti-colonial manifestations: their embrace of the Enlightenment. This section examines the different treatment the discourse of Brazilian independence affords to the two most emblematic colonial revolts inspired by the ideals of the Enlightenment: the Inconfidencia Mineira (1789) and the Inconfidência Bahiana (1798). Their study is crucial to understand the ideological formulation of independence-in particular, to determine the identification of reason with whiteness in the portrait of Brazilian independence.

$$
* * *
$$

The Inconfidencia Mineira was a plot to replace the colonial regime with an independent republic in Minas Gerais. The conspiracy was a minor affair involving less than 20 people-mostly white notables and intellectuals, with the support, more or less explicit, of merchants and large contractors, many of them Portuguese. The conspirators were inspired by the American Revolution and by their opposition to the fiscal demands of the Portuguese Crown. The prospect of independence was particularly enticing to the leading merchants and wealthy proprietors, who saw it as a way to evade paying their large debts 
to the Crown. ${ }^{17}$ The conspirators wished to end the colonial regime without upsetting the internal social structure. They invoked the ideals of liberty and equality in the context of the relation between Minas Gerais and Portugal, but did not extend the application of these ideals to the internal reality of Minas Gerais, let alone Brazil. The conspirators who dreamt about independence did not speak of Brazil but of America or Minas Gerais. ${ }^{18}$ They discussed the abolition of slavery but concluded that without slavery they would find noone to work in the mines or on the farms; paid work was obviously not a valid option. In the end, they agreed to free the local-born slaves while retaining the institution of slavery. This would provide the revolt with much needed support without causing major social readjustments. ${ }^{19}$ Its conservative social character would later turn the Inconfidencia Mineira into the popular choice amongst the white elite in their quest for the roots of independence and the Republic.

The plot was betrayed to the authorities and the participants were arrested and subjected to a lengthy and humiliating trial in Rio de Janeiro. Of the 11 death sentences, only one was carried out - that of José Joaquim da Silva Xavier, a modest army officer and occasional dentist known by the nickname of 'Tiradentes' (Tooth-Puller). Tiradentes was the only conspirator who admitted participation in the conspiracy, and the only one who did not belong to the elite of Minas Gerais. This, and his permanent advocacy of republican ideals during the trial, made him the perfect scapegoat in the eyes of the Portuguese Crown. Tiradentes was hanged, drawn and quartered on 21 April 1792 in Rio de Janeiro. The execution was to serve as a warning to those who might contemplate rising against the Crown, but the episode left an aftermath of republican sentiment in the region that would eventually spread to the whole of Brazil.

Similarly, the Inconfidencia Bahiana was a plot to replace the colonial regime with an independent and democratic republic in Bahia. The initial discussions involved a small group of men from the white elite of Bahia, but soon the majority of the conspirators were blacks and mulattos from the lower classes-mainly soldiers and artisans. The large proportion of tailors arrested led the movement to be known as the Conjuração dos Alfaiates (Conspiracy of the Tailors). There were also a significant number of slaves amongst the conspirators; 12 of those arrested were slaves - most of them born in Brazil. The presence of AfroBrazilians transformed the conspiracy into a more complex movement that saw political independence from Portugal as a means to bring to an end slavery and racial discrimination in Bahia. The free blacks and mulattos were offended by

17 Maxwell, K. R. 1973, Conflicts and Conspiracies: Brazil and Portugal, 1750-1808, Cambridge University Press, Cambridge, pp. 118-32.

18 Carvalho, J. M. de 2001, Cidadania no Brasil: O longo caminho, Civilização Brasileira, São Paulo, p. 76.

19 Maxwell, K. R. 1973, 'The generation of the 1790s and the idea of Luso-Brazilian empire', in D. Alden (ed.), Colonial Roots of Modern Brazil, University of California Press, Berkeley, Los Angeles and London, pp. 127-30. 
the multiple barriers to their social mobility, which, for example, prohibited anyone having 'black blood' or married to a woman 'of colour' from holding public office. ${ }^{20}$ In sum, the participation of Afro-Brazilians in the conspiracy raised the spectre of abolition and forced the notion of racial equality - equality between whites, blacks and mulattos - to the forefront of politics in Bahia.

The rebels posted handwritten proclamations in public places calling, amongst other things, for higher pay for troops, free trade, the equality of people of all colours, and the independence of Bahia. ${ }^{21}$ Their actions were clearly inspired by the rhetoric of the French Revolution, but also by the slave uprising of Saint Domingue, later known as the Haitian Revolution. ${ }^{22}$ The prominence of slaves, blacks and mulattos amongst the conspirators, coupled with the events of Saint Domingue, frightened the white elites of Bahia, who were not willing to risk their position of privilege for independence from Portugal. Their fear was clearly illustrated in the advice of Cipriano Barata de Almeida, a white slave owner and early conspirator, to one of his colleagues: 'My friend, caution with the African rabble.. ${ }^{23}$

The quick reaction of the authorities aborted the conspiracy. Of the 46 individuals arrested, 36 were brought to trial. The trial enabled the identification of two groups of conspirators. The first included Cipriano Barata himself, a surgeon and graduate of the University of Coimbra; Francisco Muniz Barreto d'Aragão, a teacher of rhetoric; and two military officers, Lieutenants Hermogenes Francisco d'Aguilar and José Gomes de Oliveira Borges. All four were white and socially prominent in Bahia. These men - some of whom were slave owners - showed little interest in slavery and racial inequality. Their ardour was for free trade (that is, the freedom to make money). The members of this group escaped with minimal or no punishment. The second group - those accused by the royal authorities of being the chief plotters - was formed by the soldiers Luís Gonzaga das Virgens e Veiga and Lucas Dantas de Amorím Torres, and the tailors João de Deus Nascimento and Manoel Faustino dos Santos Lins. The four - all free and poor mulattos - were found guilty and hanged. Their bodies were beheaded and quartered, and their body parts left to rot in public places around Salvador. Their execution sent a chilling warning to non-whites who dared to call for racial equality, and reassured the white population that, under the existing regime, Portuguese America would not become another Saint Domingue.

20 Azevedo, T. de 1955, As elites de cor: Um estudo de ascensão social, Companhia Editora Nacional, São Paulo, p. 232.

21 Mattoso, K. M. de Q. 1969, Presença francesa no movimento democrático baiano de 1798, Itapuã, Salvador, pp. 144-59.

22 Silva, M. B. N. da 1992, 'Liberdade, igualdade e fraternidade numa sociedade escravocrata. Bahia, 1798', in Actas do Colóquio. A recepção da Revolução Francesa em Portugal e no Brasil. Volume II, Universidade do Porto, Porto, pp. 381-94.

23 Cited in Schwartz, S. B. 1985, Sugar Plantations in the Formation of Brazilian Society: Bahia, 1550-1835, Cambridge University Press, Cambridge, p. 476. 
The Inconfidência Mineira and the Inconfidência Bahiana did not achieve their objectives, but helped shape the character of Brazilian independence. To be sure, neither of the conspiracies was an expression of Brazilianness. The eighteenth-century plots against the Portuguese Crown sought, without exception, regional autonomy, not the independence of Brazil. These regional movements revealed, however, the obstacles and dangers that would face those willing to gain independence from Portugal. The main lesson drawn by those who would eventually conduct the formal process of independence (the white political elite) was the need to separate the social from the political. Thus, the formal independence of Brazil would follow the liberal and conservative path envisaged by the leaders of the Inconfidencia Mineira. This conspiracy would later emerge as the foremost precedent for Brazilian independence, whereas the Inconfidência Bahiana would be sidelined as a minor affair in the history of colonial Brazil.

\section{$* * *$}

The Inconfidência Mineira was invoked by the national(ist) historiography after the independence of Brazil. The stance of the conspirators against the Portuguese Crown - in particular, the behaviour of Tiradentes - appealed to a nation in search of a heroic past. The regionalist and republican character of the conspiracy was, however, a direct affront to the monarchical nature of the Brazilian Empire and the effort of the authorities to consolidate the national unity of Brazil. The figure chosen by official historians - those associated with the Instituto Histórico e Geográfico Brasileiro - to define the character of the Brazilian Empire was that of Dom Pedro I. Nevertheless, the growing republican sentiment was leading to the rapid diffusion of the historical memory of Tiradentes and the Inconfidência Mineira throughout Brazil. The result: 'The struggle between the memory of Pedro I, promoted by the government, and that of Tiradentes, promoted by the republicans, became increasingly emblematic of the battle between Monarchy and Republic.'24

The Republican Manifesto of 1870 precipitated the publication of the most important study of the Inconfidência Mineira written during the Empire: Joaquim Norberto de Sousa Silva's História da Conjuração Mineira (1873). Norberto minimised the historical significance of the conspiracy and questioned the patriotism of Tiradentes. He argued that Tiradentes had been transformed during his long time in prison by the regular visits of the Franciscan friars, to the point that his patriotic fervour had turned into religious fervour: 'They had arrested a patriot; they had executed a friar.' ${ }^{25}$ Norberto interpreted his

24 Carvalho, J. M. de 1990, A formação das almas: O imaginário da República no Brasil, Companhia das Letras, São Paulo, p. 61.

25 Cited in ibid., p. 63. 
behaviour in terms of sacrifice rather than resistance-denying in the process the political significance of the death of Tiradentes. The talk of mysticism and sacrifice, however, gave Tiradentes a quasi-religious aura that enhanced his reputation as a patriotic figure, turning him into the first national martyr - the man who stood up for Brazilian independence against the tyranny of Portugal.

The centrality of Tiradentes and the Inconfidência Mineira in national(ist) historiography contrasts with the little interest shown in the Inconfidência Bahiana, even though the latter was arguably a more significant development in the history of Portuguese America. The Inconfidência Bahiana was a 'unique example of penetration - imperfect as it may have been — of the Enlightenment into the masses' in Brazil. ${ }^{26}$ This alone should be sufficient to draw attention to this event, if only to do justice to the complex history of colonial Brazil. The discrepancy between historical significance and historiographical treatment can be explained by the fact that the independence of Brazil followed the liberal (and hierarchical) model discussed by the (white) conspirators of Minas Gerais rather than the social (and egalitarian) model proposed by the (black) conspirators of Bahia. This explanation hides something deeper about the national(ist) imaginary: the whiteness of the Enlightenment in the official accounts of the colonial history of Brazil. The historiographical treatment of the Inconfidencia Bahiana, especially when contrasted with that of the Inconfidência Mineira, suggests that reason - and the ideals of liberty and equality associated with reason - was considered the exclusive attribute of the white elites, and that in the hands of non-whites those same ideals would turn into barbarism.

In the narratives of Brazilian history, the Inconfidencia Bahiana has usually been denigrated, silenced or marginalised - a fate similar to that of the Haitian Revolution in the narratives of world history. ${ }^{27}$ The early commentaries on the conspiracy focused on the character of the protagonists - portrayed as ignorant, immoral mulattos of no social standing - rather than on their thoughts and objectives. The only extensive account of the conspiracy produced during the nineteenth century was in Francisco de Varnhagen's História Geral do Brasil (1854-57). The official historian of the Brazilian Empire condemned all conspiracies against the Crown, but was particularly repelled by the Inconfidencia Bahiana, which conjured violent images of radical France, and especially of revolutionary Saint Domingue. The accounts of the conspiracy evoked images of a mutinous black rabble running amok, lacking control and civilised standards of behaviour, confusing freedom with licentiousness, political change with social disorder. The implication was that people of low status in general, and non-whites in particular, could not be rational political agents.

26 Burns, E. B. 1970, A History of Brazil, Columbia University Press, New York and London, p. 98.

27 Trouillot, M.-R. 1995, Silencing the Past: Power and the production of history, Beacon Press, Boston. 
Historical narratives continue to apply a double standard to the Inconfidencia Mineira and the Inconfidência Bahiana. The general idea stands that the former failed because it was betrayed, whereas the latter failed because of the ignorance and ineptitude of its leaders. Significantly, the behaviour of Tiradentes was also considered by many of his contemporaries as irrational, crazy and dangerous, not least because he was also a person of low social status. ${ }^{28}$ His actions, however, were subsequently reinvented as those of a visionary, someone who was anticipating the future of Brazil. Thus, while the actions of Tiradentes have been celebrated and his political errors excused by his enthusiasm and idealism, the idealism and political errors of the Afro-Brazilian conspirators of Bahia continue to be explained in terms of naivety and precipitation. ${ }^{29}$ The refusal to attribute political rationality to their actions makes reason and political agency synonymous with the actions of the Luso-Brazilians, privileging white(nes)s in the formulation of Brazilian independence.

\section{The Politics of the Possible in the Age of Revolt}

The independence of Brazil cannot be regarded simply in relation to Portugal, but also in relation to the process of internal unity - without which there would be no Brazil (as we know it) and thus no Brazilian independence. The analysis of this process brings to light the conflict and violence that underpinned the formation of Brazil in the years that surrounded its independence from Portugal. This period - characterised by social unrest and political instability - can be dated from 1817, the year of the Revolution of Pernambuco, to 1850, the year of the consolidation of the nation-state of Brazil. This age of revolt refutes the myth of a peaceful social and political integration commonly associated with Brazilian independence. Moreover, the historical accounts of these revolts reveal a concept of politics that denies most of the population - especially Brazilian Indians and Afro-Brazilians - political agency in the formation of Brazil(ianness).

$$
* * *
$$

The Revolution of Pernambuco was a reaction against the centralisation of power and the increased tax burdens that followed the transfer of the Portuguese Court to Rio de Janeiro. The revolt was driven by the resentment of the regional elite for their loss of autonomy to Rio de Janeiro and the official favouritism shown to the Portuguese. The revolt found support amongst the military, public officials,

28 Mota, C. G. 1971, Atitudes de inovação no Brasil, 1789-1801, Livros Horizonte, Lisboa, p. 68.

29 Teixeira, F. M. P. 1993, História concisa do Brasil, Global, São Paulo, p. 101. 
landowners, men of letters, judges, artisans, merchants, and a large number of priests. The rebels established a new regime based on liberal ideals, including the sanctity of private property. The leaders of the provisional government reassured slave owners: 'Patriots, your property rights are sacred, no matter how repugnant this may be to the ideal of justice. ${ }^{30}$ The liberal experiment was short-lived, lasting only 74 days. The defeat of the rebels was followed by a brutal repression and the sending of fresh troops from Portugal to Rio de Janeiro, Salvador and Recife.

The provinces of the north-east that had participated in the revolution of 1817 refused to accept a constitution imposed on them by the Emperor and that concentrated power in Rio de Janeiro. In 1824, the rebels seized power and proclaimed the Confederation of the Equator. The revolt was a direct affront to the monarchical character of the Empire, not to mention to the unity of Brazil. But the rebels did not intend to change the social order. In fact, they resented the involvement of blacks and mulattos in the revolt because it reminded them of 'the scenes of Saint Domingue'. ${ }^{31}$ Their preoccupation was with attaining autonomy over economic interests and commerce - that is, with the control of the state. In the event, the revolt suffered from the same lack of cohesion and rashness in action that had doomed the revolution of 1817. The short-lived separation was crushed by the troops of the British Admiral Cochrane and followed by numerous executions - the most prominent being that of the liberal priest known as Frei Caneca.

The Revolution of Pernambuco and the Confederation of the Equator were discredited by imperial historians, but became objects of veneration in the history of the north-east, and patriotic landmarks in the nationalist accounts of Brazilian independence. The revolts entered the national imaginary as the continuation of the spirit of independence and Brazilianness that nationalist historians attribute to the Guerra dos Mascates (1710) and the Inconfidencia Mineira (1789). Frei Caneca, the most prominent intellectual of Pernambuco at the time, was portrayed by nationalist historians as a 'martyr of Brazilian freedom' despite the fact that his vision of the nation was dominated by a strong regional(ist) feeling, and that his political formula tried to bring together the 'Portuguese of Europe' and the 'Portuguese of Brazil' but gave no consideration to Brazilian Indians and Afro-Brazilians. ${ }^{32}$ In short, this interpretation of

\footnotetext{
30 Costa, E. V. da 1975, 'The political emancipation of Brazil', in A. J. R. Russell-Wood (ed.), From Colony to Nation: Essays on the independence of Brazil, Johns Hopkins University Press, Baltimore and London, p. 64. 31 Francisco Muniz Barreto d'Aragão cited in Moura, C. [1987] 1993, Quilombos: Resistência ao escravismo, (Third edition), Ática, São Paulo, p. 69.

32 Lyra, M. de L. V. 1998, “"Pátria do cidadão”: a concepção de pátria/nação em Frei Caneca', Revista Brasileira de História, no. 18.
} 
the liberal revolts not only obviates their regional(ist) character but, more importantly, extracts the political essence of the nation exclusively from the actions and thoughts of the white elites of Brazil, the Portuguese of America.

The continuation of past injustices and the inability of the imperial authorities to secure national unity without violence tarnished the popularity of Dom Pedro soon after independence. In 1831, pressure from the Brazilian political leaders, combined with demonstrations in the streets of Rio de Janeiro, finally led him to abdicate in favour of his Brazilian-born five-year-old son, Dom Pedro de Alcântara, the future Dom Pedro II. The abdication furthered the nationalisation of the throne and marked the completion of political independence from Portugal. The date 17 April was placed alongside 7 September as the other crucial date of Brazilian independence: the Second Independence. Manoel Bomfim defined the events of 1831 in revolutionary terms and placed them alongside the revolution of 1817 as the true essence of Brazilian nationalism, in what constitutes further illustration of the narrow definition of Brazilianness that informs the nationalist accounts of the political history of Brazil.

$$
* * *
$$

The Eurocentrism of these accounts becomes even more acute when dealing with the revolts that followed the abdication of Dom Pedro. His abdication to the throne was followed by two decades of unrest and insurrections across the whole country, including: the Cabanos War in Pernambuco (1832-35), the Cabanagem in Pará (1835-40), the Sabinada in Bahia (1837-38), the Balaiada in Maranhão (1838-41), the Farroupilha in Rio Grande do Sul (1835-45), and the Praieira in Pernambuco (1848-49). These revolts are generally interpreted as movements against the Portuguese, and other foreign influences, in postindependence Brazil (that is, as expressions of nationalism) and/or as movements of opposition to the policies of the imperial government in Rio de Janeiro (that is, as expressions of regionalism). In both cases, their interest and historical importance are determined by their impact on the formation of the Brazilian state, and even more so by the size of their threat to the political unity of Brazil. This focus on the struggle over institutional power (between nationals and foreigners, and between the capital and the provinces) has often led historians to overlook the specificity and underestimate the complexity of the different revolts, as well as to create a hierarchy of revolts (and rebels) that privileges the actions of Luso-Brazilians and ignores or minimises those of Afro-Brazilians and Brazilian Indians.

The Eurocentrism of these accounts can be illustrated by examining, for example, the historiography of the Cabanagem - a civil war that devastated much of the Brazilian north-east. This conflict lacks a clear beginning and a clear end, but 
can be roughly dated between 1831 and 1841, with its acute phase from 1835 to 1836 . The revolt began as a movement towards political autonomy led by the regional elite of Pará. The political instability created by the disputes amongst the local elites soon gave way, however, to a broader conflict across the Brazilian north-east. The conflict reflected the dissatisfaction of non-whites with a regime that kept them in poverty and slavery. In 1835, the rebels took the capital, Belém, and declared the independence of Pará. The imperial authorities sent a coalition of imperial troops and foreign mercenaries to regain control over a region thought to be 'lost altogether to the civilised world'. ${ }^{33}$ The Court turned to Marechal Francisco José de Andreá, who took control of the capital on 13 May 1836. The conflict continued in the interior, extending outside the eastern Amazon, but would never again threaten the territorial integrity of the Brazilian Empire.

The visions of the Cabanagem have been expertly analysed by Luís Balkar Sá Peixoto Pinheiro in Visões da Cabanagem (2001). Pinheiro reveals how the Cabanagem was initially interpreted as a 'Spectacle of Barbarism'. The historians and ideologues of the Brazilian Empire portrayed the rebels as scum, criminals, irrational beings, even animals. The imperial accounts spoke of a cruel, primitive, and ignorant people whose actions were opportunistic and derived from basic instincts such as hatred, revenge, and violence. This derogatory portrait of the rebels ignored their motives and demands, and justified the carnage - some have even called it genocide - that followed the arrival of Marechal Andréa. ${ }^{34}$

The centenary of the rebellion witnessed a revision of the Cabanagem that portrayed the rebels (known as cabanos: people who lived in cabins) as heroes of regional and national liberation. The transformation of the revolt into a movement of political liberation took place through a process of whitening that attributed political agency exclusively to the white elite and emptied the movement of social criticism. Those who took part in the early stages of the revolt (the white elites) became the true, ideal cabanos. The rest of the participantsthe real cabanos: those who actually lived in cabins - came to occupy the place of extras. The white rebels were praised for their high ideals and leadership qualities, whereas the non-white rebels were 'merely attributed the courage, good will and hope of seeing their wishes realised by the just, conscious and well-intentioned persons who guided them' ${ }^{35}$

This portrait of the revolt explains the ease with which local authorities and official historians chose 13 May 1936 to celebrate the centenary of the

33 Cleary, D. 1998, “Lost altogether to the civilized world": race and the Cabanagem in northern Brazil, 1750 to 1850', Comparative Studies in Society and History, vol. 40, no. 1, p. 127.

34 Pinheiro, L. B. Sá P. 2001, Visões da Cabanagem: Uma revolta popular e suas representações na historiografia, Valer, Manaus, pp. 39-62.

35 Ibid., p. 81. 
Cabanagem, culminating in the erection of a statue to Marechal Andréa, who came to be known as the Peace-Maker (Pacificador) of Pará. The commemoration framed regionalism and nationalism in a liberal discourse of law and order that celebrated the re-establishment of institutional order and removed the popular rebels from the heroic portrait of the revolt, even though they had turned the revolt from a minor affair into a major event. This vision of the Cabanagem portrayed the revolt as a nativist movement, loyal to the Empire, fighting against pro-Portuguese presidents nominated from Rio de Janeiro. The savages of the imperial accounts were transformed in the nativist narratives into noble savages brandishing the flag of Brazil(ianness). ${ }^{36}$

The liberal vision of the Cabanagem has coexisted with a socialist vision that argues for the centrality of the popular masses in the revolt. This vision came to life as part of an effort to rehabilitate the place of the people in the history of Brazil. This process, initiated by João Capistrano de Abreu-often referred to as the 'historian of the people' - in the early twentieth century, was turned into an academic movement in the 1930s by a group of Marxist historians, the most eminent of whom was Caio Prado jr. This new discourse, informed by historical materialism, has defined popular revolts, first and foremost, as class struggles. These authors rejected the visions of barbarism, insanity, and inherent cruelty attributed to the popular classes who participated in the Cabanagem. Instead, they explained the rebellion of the popular masses as a logical reaction against their oppression. Yet, the actions of the people appear to be instinctive rather than rational: at best, in need of direction; at worst, easily manipulated by those with ambitions of power. ${ }^{37}$

In sum, the exclusion and deprecation of the Cabanagem in imperial accounts have been replaced with a more subtle but equally disempowering discourse that has reduced the popular rebels to the role of extras (rather than actors) or a source of energy (rather than ideas). In the final analysis, the white liberal elite continues to be the only historical agent, or, more precisely, the only rational agent in the history of the Cabanagem. For their part, the popular (mostly nonwhite) segments continue to appear as extras or irrational beings in a movement defined by the ideas and actions of others, by the white elites inspired by the high ideals emanating from Europe.

$$
* * *
$$

Similar discursive trajectories to that of the Cabanagem can be observed in the historical accounts of other revolts that took place during the period of consolidation of the nation-state in Brazil. Caio Prado jr was one of the first

36 Ibid., p. 74.

37 Ibid., pp. 89-106. 
scholars to note that popular movements were viewed by most historians as 'facts without more significance' than the 'explosion of bestial sentiments and passions of the masses' ${ }^{38}$ He rejected this interpretation but continued to define popular rebellions as acts of instinctive violence - natural and understandable reactions against centuries of oppression and exploitation, but not rationally articulated ones. In this view, the rebels lack ideology, ideals and plans beyond the motivation of revenge and the use of violence. Thus, their rebellion translates mainly into personal attacks rather than struggles against the system. Such an interpretation simplifies the motives, strategies and objectives of many popular revolts, and equates the arguably simple means used by the rebels with their level of rationality, ignoring the fact that more often than not the rebels were simply - but not simplistically - acting out a politics of the possible.

The articulation of this politics of the possible in popular revolts is clearly illustrated in João José Reis's account of the Revolução dos Malês - the uprising of the Muslim Africans of Bahia that took place in 1835 - entitled in its English translation Slave Rebellion in Bahia (1993). This event was arguably the most important black urban rebellion in the Americas, yet it is conspicuously absent from most historical accounts of the formation of the nation-state in Brazil. The uprising was the culmination of a long cycle of Afro-Brazilian revolts that dominated life in the region after 1798, and which were partly inspired by the Haitian Revolution. These were not mere revolts against slavery, but often revolts for (racial) equality. This was the case of the Revolução dos Malês, which was led by free blacks and mulattos. Reis's work provides a comprehensive historical account and political analysis of the uprising, illustrating the objectives, tactics and actions of the rebels. The portrait of the uprising that emerges from his analysis is that of a political rebellion with clear objectives and a plan of action destined to put an end to white domination in Bahia. Moreover, this work reveals how their plans were based on a complex evaluation of what the rebels thought was the correlation of forces in Bahia in $1835 .{ }^{39}$

The exclusion of popular movements from - or their selective and subordinate incorporation into - the political history of Brazil goes hand-in-hand with their widespread consideration as pre-political manifestations. Their definition in terms of evolution (pre-political versus political) to denote difference (social versus political) reveals the higher value attached to political revolts (usually defined in liberal terms). This distinction not only obscures the complexity of forces and interests at play in the different revolts but, more importantly, it serves to establish a hierarchy of revolts that privileges political revolts (viewed

\footnotetext{
38 Prado, C. jr [1933] 1963, Evolução política do Brasil e outros estudos, (Fourth edition), Brasiliense, São Paulo, p. 8.

39 Reis, J. J. 1993, Slave Rebellion in Brazil: The Muslim uprising of 1835 in Bahia, Translated by Arthur Brakel, Johns Hopkins University Press, Baltimore and London.
} 
as complex, rational, informed by high ideals) over social revolts (viewed as simple, emotional, driven by basic needs). In other words, it privileges revolts preoccupied with institutional change and led by the white elites, in detriment of those preoccupied with broader social and political change (that is, revolts against slavery, poverty and discrimination) and led mostly by non-whites. Moreover, the term pre-political often suggests that non-white rebels cannot grasp the notion of modern politics (understood in liberal terms: institutional and representative) and thus they come across as pre-modern subjects (that is, inferior and/or backward).

The narrow definition of politics as liberal and formal (that is, institutional) sidelines the fact that the essence of politics is power, not associations and institutions - these are merely mechanisms to articulate power - and, therefore, overlooks the fact that social revolts, in so far as they seek to change the balance of power, are always political. In other words, this narrow definition of politics denies the political nature of popular rebellions, whose so-called social nature ignores the fact that popular rebels were simply acting out the politics of the possible. The ultimate effect of this distinction is to minimise the presence, when not erasing the political agency, of Brazilian Indians and Afro-Brazilians from the historical memory of Brazil.

In short, the age of revolt that took place in the mid nineteenth century illustrates the widespread discontent that followed the independence of Brazil, pointing out the problems that did not end with the separation from Portugal. The national(ist) accounts of this age of revolt produce a double narrative: one of political revolts (led by whites) seeking to liberate the nation from external control, which were eventually successful, and with little, if any, bloodshed; and one of social revolts (led by non-whites) seeking to fulfil particular needs, driven by emotions and violence, which were responsible for immense bloodshed, but were dissociated from the struggle for Brazilian independence. This double narrative reinforces the white hegemony and the Eurocentrism that define the portrait of Brazilian independence.

\section{Conclusion}

The idyllic portrait of Brazilian independence formulated in the nineteenth century has survived virtually unscathed into the twenty-first century. This is the portrait of a cordial and peaceful process, led by a rational and reasonable (white and male) political elite, which culminated in the harmonious integration of the different peoples and regions of Brazil into a single and unified nationstate. In this narrative, Brazilian independence is the culmination of a teleological process - more a matter of destiny than a matter of contingency. This portrait 
rests largely on the symbolic power of the Grito de Ipiranga. The notion that independence came about with a simple (royal) cry-without a single shot being fired - symbolises the peaceful nature of Brazilian independence.

Yet, as we have seen, this is an idealised (and ideological) portrait that omits and distorts essential aspects that are necessary to fully comprehend Brazilian independence, let alone the formation of the nation-state in Brazil. Above all, this portrait glosses over the fact that Brazilian independence was preceded, accompanied and followed by violent conflicts across all regions of the country, involving all sectors of the population. Moreover, this exorcism of political violence from the portrait (and the process) of Brazilian independence betrays a double standard in the historiographical treatment of anti-colonial resistance in Brazil. On the one hand, the anti-colonial revolts carried out by Luso-Brazilians against their External Others-initially the European rivals of Portugal for the control of Brazil, and then Portugal itself-are defined as political, rational, and modern, and are integrated into the teleological narrative of Brazilian independence. On the other hand, the anti-colonial revolts carried out by the Internal Others of the Luso-Brazilians (that is, Brazilian Indians and Afro-Brazilians) are defined as pre-political, irrational, and primitive, and are dissociated from the portrait of Brazilian independence. Thus, Brazilian independence becomes synonymous with Luso-Brazilian agency, entrenching Eurocentrism and white hegemony in the (re)birth of Brazil. 